\title{
JLEET
}

Journal of Language Education and Educational Technology

Volume 6 No. 1, 2021

e-ISSN: 2502-3306

\section{An Analysis of Politeness in Teacher's Utterances in an English Classroom}

\author{
Risal, Hanna, Tambunan
}

Halu Oleo University, Indonesia.

\begin{tabular}{|c|c|}
\hline ARTICLE INFO & ABSTRACT \\
\hline $\begin{array}{l}\text { Keywords: } \\
\text { Pragmatics, Politeness } \\
\text { Strategies, Teacher's } \\
\text { Utterances, English } \\
\text { Classroom } \\
\text { DOI: } \\
\text { http://dx.doi.org/10.33772/jleet.v6i1.17583 }\end{array}$ & $\begin{array}{l}\text { The objectives of this research were three-fold: to } \\
\text { explore the types of politeness uttered by the teacher, to } \\
\text { analyze the most predominant type of politeness } \\
\text { uttered, and to explore the strategies of politeness } \\
\text { uttered by the teacher in an English classroom. This } \\
\text { research employed a descriptive qualitative analysis. } \\
\text { The subject of this research was an English teacher of } \\
\text { MAN } 1 \text { Kolaka. This research was conducted with two } \\
\text { cohorts; they were class XII.IA-2 and class XII.IA-4. The } \\
\text { data were collected from three observations and } \\
\text { recordings of teacher's utterances. As many as } 117 \\
\text { politeness utterances were identified, encompassing } 55 \\
\text { positive politeness utterances, } 45 \text { negative politeness } \\
\text { utterances, } 6 \text { bald on record utterances and } 1 \text { off record } \\
\text { utterance. There were } 17 \text { strategies of politeness used by } \\
\text { the English teacher. The most predominant type of } \\
\text { politeness was positive politeness, including the } \\
\text { strategies of exaggerating sympathy with the Hearer, } \\
\text { which was used } 3 \text { times, including both the Speaker } \\
\text { and the Hearer } 6 \text { times, giving gifts to Hearer } 26 \text { times, } \\
\text { being optimistic } 10 \text { times, offering } 2 \text { times, notice attend } \\
\text { to Hearer } 4 \text { times, using group identity mark } 3 \text { times, } \\
\text { and Intensifying interest to the hearer } 1 \text { time. }\end{array}$ \\
\hline
\end{tabular}

\section{INTRODUCTION}

Being polite is a complicated matter in any language. It is difficult to be learned because it involves understanding not only the language, but also the social and cultural values 
of the community. In the case of communication or daily conversation, there are two levels of speech that are normally used, namely polite speech and familiar speech. Generally speaking, polite speech is used in social situations such as a conversation between acquaintances or strangers (Mahmud, 2010). Some sociolinguists have defined politeness. The most important idea of politeness comes from Brown and Levinson, who stated that politeness essentially 'funds fulfilling communicative and face-oriented ends, in a strictly formal system of rational practical reasoning' (Brown and Levinson, 1987). Brown and Levinson (1987) stated that politeness strategies are urbanized to save the hearer's 'face'. Face refers to the deference that an individual has for him or herself, and the maintaining of "self-esteem" in public or personal situations. In this case, usually, the speakers attempt to stay away from embarrassing another person, or making him feel uncomfortable.

This research was intended to answer the following questions: (1) what types of politeness were uttered by an English teacher in English classroom interaction? (2) What was the most predominant type of politeness uttered by the teacher in the English classroom? (3) What strategies of politeness were uttered by the teacher in English classroom interaction?

\section{LITERATURE REVIEW}

Pragmatics is a subdivision of linguistic studying the part of meaning and language use. Parker (1986) defines pragmatic as the study of how language is used for communication. Citizens typically communicate their ideas through conversation. A conversation is a communication between multiple people that consists of the speaker(S) and hearer $(\mathrm{H})$ or addressee $(\mathrm{A})$. Speaker is an individual who speaks particular words. A hearer is an individual who hears the words spoken by the speaker. Addressee is an individual to whom the words are addressed. In a conversation, an addressee must be the hearer too. But a hearer is not necessarily the addressee. It depends on the number of people involved in the conversation. In a conversation, people need to be careful in using a strategy to maintain the communication. They also must be aware of politeness strategy to make their communication more acceptable to others.

Brown and Levinson's politeness assumption comprises five strategies: (a) to pursue what it says, bald on record, (b) perform speech acts using positive politeness (refers to the positive face), (c) perform speech acts using negative politeness (refers to the face of a negative), (d) indirect speech act (off the record), and (e) do not do speech act or say anything (do not do the FTA). In connection with this politeness strategy, here are the possible strategies for doing FTAs. 


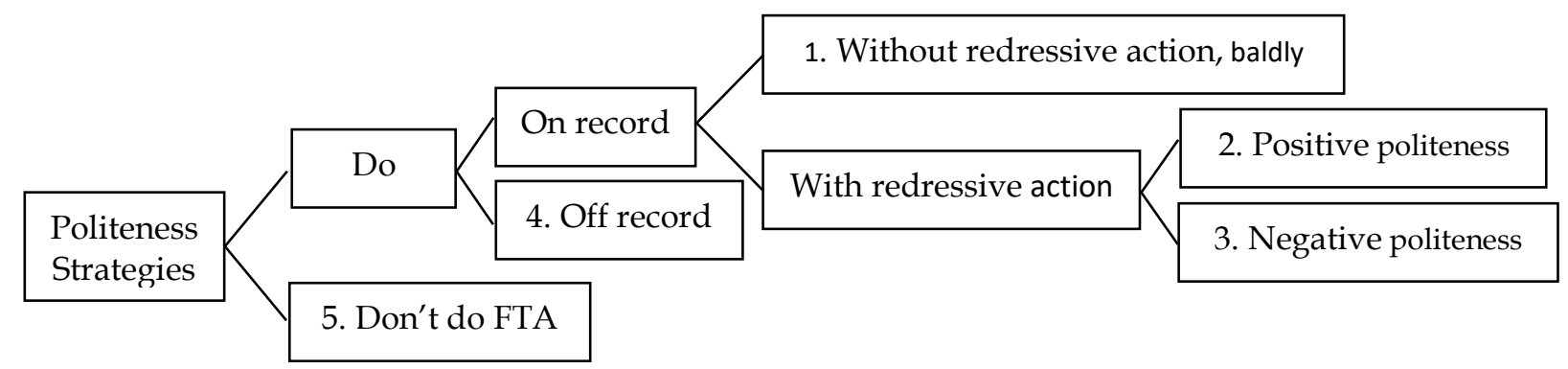

Figure 1. Possible strategies for doing FTAs (Brown \& Levinson, 1987: 69)

Qualitative research is of specific relevance to the study of social relations, due to the fact of the pluralization of life worlds. Qualitative research can be defined as the collection, analysis, interpretation of comprehensive narrative and visual data to obtain insight into a particular phenomenon of interest (Flick, 2009).

\section{METHODS}

\subsection{Respondent}

This research was conducted at MAN 1 Kolaka. The research subject was an English teacher of MAN 1 Kolaka. To determine the subject, the researcher applied the purposive sampling technique. The teacher had extensive experience teaching in this particular school context. Data collection was conducted on February, 10th, 17th, and 24th 2020. The researcher did the observation over three meetings. Two cohorts of students participated in this research; they were class XII.IA-2 and class XII.IA-4.

\subsection{Data Collection}

The following are the procedures of data collection. First, the researcher found the information of the class schedule. Then, the observation time was determined after gaining consent from the teacher. The observation was conducted during the learning process. In this case, the researcher observed and recorded all the teacher's utterances. Data collection process ceased when when data obtained was exhaustive.

The next step was transcribing the utterances of the teacher. If data had been recorded using technical media, their transcription is a fundamental stage on the way to their interpretation (Flick, 2009). Therefore, the data of utterances collected from the observation was transcribed. This stage was conducted to facilitate the researcher to analyze the types and functions of politeness strategy uttered by the students during the learning process in the English classroom. Upon completing data transciption, the next step was categorising the data based on Brown and Levinson classifications where frequency of occurence of certain politeness address and strategies was examined.

\section{FINDINGS AND DISCUSSION}

\subsection{Findings}


In the first observation, 57 utterances of politeness strategy were used by the observed teacher. These 57 utterances derived from 3 types of politeness such as "positive politeness" (25 utterances), "negative politeness" (27 utterances), and "bald on record" (5 utterances). Interestingly, the teacher did not employ any "off record" strategy. Thus, the most predominant was negative politeness.

The teaching-learning process somprised opening, main, and closing activities. For the opening activity, the teacher produced 4 utterances containing positive politeness and negative politeness strategies. Positive politeness occured twice with the strategies of exaggerating (interest, approval, sympathy with Hearer) and include both Speaker and Hearer in the activity, whereas negative politeness also occured twice with the strategies of "minimizing the imposition".

In the main activity, the teacher produced 46 utterances of politeness strategies. Positive politeness is divided into 4 strategies such as "include both Speaker and Hearer in the activity" (occurence 1), giving gifts (occurence 9), be optimistic (occurence 4), and offering (occurence 1). Negative politeness comprised "question and hedge" (occurence 12), be pessimistic (occurence 9), minimizing the imposition (occurence 2), impersonalize Speaker and Hearer (occurence 1), and be conventionally indirect (occurence 2), while "bald on record deriving from imperative" (occurence 2), requesting (occurence 2), and warning (occurence 1 ).

In the closing activity the teacher employed 7 utterances of positive politeness strategies that originated from 4 strategies: include both Speaker and Hearer (occurence 1 ), notice attend to Hearer (occurence 1), giving gifts (occurence 3), and be optimistic (occurence 2). Thus, the most predominant politeness strategies used by the teacher in the first observation was a question, hedge of negative politeness. It was found with a total of 12 utterances. The teacher used question strategies during observation activity (occurence 3), 4 times in questioning activity, 2 times in experimenting activity, 1 time in associating activity, and 2 times in communicating activity. Thus, the teacher used the most questioning strategy for negative politeness with total occurance of 12 times.

In the second observation, 30 utterances of politeness strategy were produced by the teacher. These 30 utterances came from 3 types of politeness: positive politeness (18 utterances), negative politeness (11 utterances) and bald on record ( 1 utterance). The teacher didn't use any off record in the second meeting. Thus, the most predominant politeness strategy was positive politeness.

The teaching-learning process encompassed opening to closing activities. For the opening activity, the teacher produced 4 utterances that contained positive politeness strategy (occurance 2) and negative politeness (occurance 2). Positive politeness involve the strategies of exaggerating (interest, approval, sympathy with $\mathrm{H}$ ) and include both Speaker and Hearer in the activity. While negative politeness involve the strategies of minimizing the imposition.

In the main activity, the teacher produced 22 utterances of politeness strategies. Positive politeness is further divided into 6 strategies: "include both Speaker and Hearer in the activity (occurence 2), "giving gifts" (occurence 6), be optimistic (occurence 2), "offering" (occurence 1), "notice attend to hearer" (occurence 1), and 
"using group identity marker" (occurence 1). Negative politeness came from question, hedge (occurence 3), be pessimistic (occurence 2), "minimizing the imposition" (occurence 1), and "be conventionally indirect" (occurence 2) and "bald on record came from imperative" (occurence 1).

In the closing activity, the teacher produced 4 utterances of positive politeness strategies that derived from 3 strategies: "notice attend to Hearer" (occurence 1), "giving gifts" (occurence 1), and be optimistic (occurence 1), while negative politeness came from "minimizing the imposition" (occurence 1).

The most predominant politeness strategies used by the teacher in the second meeting was "giving gifts" with a total of 7 utterances. The teacher used the giving gifts strategy twice in observing activity, once in questioning activity, once in experimenting activity, once in associating activity, and twice in communicating activity. Thus, the the giving gifts was the most predominant of positive politeness with the total occurence of 7 times.

In the third observation, there were 30 utterances of politeness strategy used by the teacher. These 30 utterances came from 3 strategies: "positive politeness" (occurence 20), negative politeness (occurence 9) and bald off record (occurence 1) and the teacher. Thus, positive politeness was the most predominantly used.

The teaching-learning process was conducted from opening to closing activities. For the opening activity, the teacher used 4 utterances that contained positive politeness strategy and negative politeness. Positive politeness (occurence 2) with the strategies of include both Speaker and Hearer in the activity, while negative politeness (occurence 2) involved the strategies of minimizing the imposition.

In the main activity, the teacher produced 22 utterances of politeness strategies. Positive politeness is divided into 7 strategies: "giving gifts" (occurence 6), "be optimistic" (occurence 2), "using in group identity marker" (occurence 2), "intensifying interest to the hearer" (occurence 1), "avoid disagreement" (occurence 1), " include both Speaker and Hearer in activity (occurence 2), and "notice attend to Hearer" (occurence 1). Negative politeness came from "being pessimistic" (occurence 1), "minimizing the imposition" (occurence 2), "be conventionally indirect" (occurence 1), "apologies" (occurence 1), and impersonalize Speaker and Hearer (occurence 1), while "bald off record" came from giving hints (occurence 1).

In the closing activity, the teacher produced 4 utterances of positive politeness strategies that came from 2 strategies: "giving gifts" (occurence 3), and "include both Speaker and Hearer in the activity" (occurence 1).

Thus, the most predominant politeness strategies used by the teacher in the second meeting was "giving gifts" of positive politeness (occurence 6). The teacher used the giving gifts strategy once in observing activity, once in questioning activity, once in experimenting activity, once in associating activity, and twice in communicating activity.

\subsection{Discussion}


As mentioned in the previous chapter, the research aimed to reveal types of politeness, the most predominant type of politeness uttered by the teacher, and the strategies of politeness uttered by the teacher in English classroom interaction. In the present study, Brown and Levinson's politeness strategy was used to describe types of politeness, the most predominant type of politeness, and the strategies of politeness uttered by the teacher in English classroom interaction.

As many as 117 utterances have been identified as polite utterances and there were 4 types of politeness uttered by the English teacher during teaching-learning process at MAN 1 Kolaka. They were positive politeness, negative politeness, bald on record and off record. Positive politeness was used 55 times by the English teacher. Positive face refers to every individual's basic desire for their public self-image that wants to be shown: engagement, ratification, and appreciation from others, want to be wanted. The FTA is performed utilizing strategies oriented toward the positive face threat to the hearer. A positive politeness strategy is usually seen in a group of friends, or where people in the given social situation know each other fairly well. They usually try to minimize the distance between them by expressing friendliness and interest in the hearer's need to be respected (minimize the FTA). The only feature that distinguishes positive politeness compensation from normal language behavior is an element of exaggeration. The English teachers used positive politeness in the teaching-learning process because he/she wanted to be closer to the students to enable good interaction in the teaching-learning process.

By comparison, negative politeness was used 45 times intended to avoid offending others by showing differences. Brown and Levinson divided negative politeness into being indirect, question or hedge, being pessimistic, minimize imposition, apologize, impersonalize speaker and hearer, state the FTA as the general rule, nominalize, go on record as incurring debt, or as not indebting hearer, not presuming/assuming, not concerning Hearer, communicating Speaker's want to not impinge on Hearer, redressing other wants of Hearer's. For example, when the teacher commanded to the students "Ok dear, would you help me to explain it, please!", the teacher used the word "Please" in her order. In this utterance, hedge functioned to soften command.

Finally, off-record strategy was rarely used by the English teacher. This strategy occurred only once. The off-record strategy is a politeness strategy that relies upon implication. This strategy is very indirect and involves the breaking of conversational norms to imply a particular recommended course of action. For example, the teacher said "Your whiteboard is very dirty", which can be understood as asking students to clean the whiteboard indirectly.

In addition to polite utterances, 17 strategies were also identified as belonging to positive politeness (occurence 55) including the strategies of "exaggerating sympathy with Hearer" (occurence 3), "include both Speaker and Hearer in the activity" (occurence 6), "giving gifts to Hearer" (occurence 26), "being optimistic" (occurence 10), "offering" (occurence 2), "notice attend to Hearer' (occurence 4), "using group identity mark" (occurence 3), and "intensifying interest to the Hearer" (occurence 1). By comparison, negative politeness (occurence 45) including the strategies of "minimize 
the imposition" (occurence 12), "question, hedge" (occurence 15), "be pessimistic" (occurence 11), "impersonalize Speaker and Hearer" (occurence 2), and "be conventionally indirect" (occurence 5). The third is "bald on record" (6 utterances) including the strategies of "imperative" (occurence 3), "requesting" (occurence 2), and "warning" (occurence 1), while off-record politeness was 1 utterance including the strategies of giving Hints used in just once.

Based on the data of the teacher's utterances above, it was found that the most predominant type of politeness uttered by the English teacher was positive politeness which includes the strategies of exaggerating sympathy with Hearer (occurence 3), include both Speaker and Hearer in the activity (occurence 6), giving gifts to Hearer (occurence 26), being optimistic (occurence 10), offering (occurence 2), notice attend to Hearer (occurence 4), using group identity mark (occurence 3), and intensifying interest to the Hearer (occurence 1). The teacher used the strategies of giving gifts more rather than other strategies. This strategy can be realized in the form of giving special attention to the Hearer. This strategy redresses students' faces directly by fulfilling some of the Hearer's wants in indicating that the Speaker wants Hearer's want. The teacher's utterance indicates that he respected the students' want and tried to understand them. Simply put, the teacher has a good emotional relationship with their students.

\section{CONCLUSION}

Based on the finding and discussion of this research, this research has two conclusions. First, there were four types of politeness strategies uttered by the teacher in English classroom communication during the learning process: positive politeness, negative politeness, bald on record, and off record. Each type of politeness strategy was uttered by the teacher in English classroom interaction functioned differently. And the teacher used positive politeness more predominantly during English classroom interaction.

\section{References}

Bousfield, Derek. 2008. Impoliteness in the struggle for power, di Derek Bousfield dan Miriam A. Locher (Eds.), Impoliteness in Language: Studies on its Interplay with Power in Theory and Practice. Berlin: Mouton de Gruyter, 127-154.

Brown, P. and Levinson, S. C. (1987).Politeness: Some universals in Language Usage. Cambridge: Cambridge University Press.

Consolo, D. A. (2006).Classroom Oral Interaction in Foreign Language Lessons and Implications for Teacher Development. Linguagem \& Ensino,9(2), 33-500

Findlay, M. S. (1998). Language and Communication: A cross-cultural Encyclopedia. Santa Barbara California: ABC-CLIO.

Fitriyana, Yuli. 2007. Politeness Strategies in John Grisham's novel "The Client". Thesis. Malang: English Letters and Language Department, UIN Malang. Unpublished

Fraser, B. and Nolen, W. (1990).The Association of Defense with Linguistic Form.International Journalof the Sociology ofLanguage, 27, 93-109.

Fukushima, Saeko. (2003). Request and culture:Politeness in British English and Japanese,

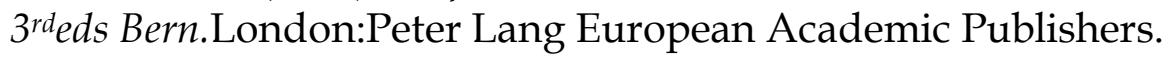


Greetz, C. (1960). The Religion of Java.Glencoe III: Free Press. Excerpted in Fishman (1968) and Pride and Holmes (1972). London

Goffman, E. (1967). On Face-work: An Analysis of Ritual Elements of Social Interaction. Psychiatry:Journal for the Study of Interpersonal Processes, 18(3), 213-231.

Geyer, N. (2008). Discourse and Politeness: Ambivalent Face in Japanese. Continuum.

Goody, Esther N. 1996. Question And Politeness. Cambrige: Cambridge University

Grice, H. (1975). Logic and Conversation. In P. Cole \& J. Morgan (Eds.), Syntax and semantics 3: Speech acts.New York: Academic Press.

Grundy, Peter. 2000. Doing Pragmatics. New York: Oxford University Press.Holmes, Janet. 1992. An Introduction to Sociolinguistik. England: Longman Group UK.

Holmes, J. (2003). Women, Men and Politeness. New York: Longman.

Kasper, G. (1997).Second Language Teaching and Curriculum Center, University Of Hawaii.Retrieved February,2012, from $<$ http:// www.nflrc.hawaii.edu/NetWorks/NW06/default.html >

Kitao, K. (1988). Differences Between Politeness Strategies Used in Request by American and Japanese. Available (online) http://www.Doshisha.ac

Kitamura. N. (2001). Politeness Phenomena and Mild Conflict in Japanese Casual Conversation. Unpublished PhD thesis. Sydney: University of Sydney

Lakoff, Robin T. 1990. Talking Power: The Politics of Language in Our Lives. Glasgow: Harper Collins

Lakoff, R. T. (1976). Language and Woman's Place.NewYork: Octagon Books.

Lakoff, R. (1973) 'The logic of politeness; or, minding your p's and q's.' In: Corum, C., Smith-Stark, T. and Weiser, A. (eds) Papers from the Ninth Regional Meeting. Chicago Linguistic Society. Chicago. 292-305.

Leech, G. (1983). Principles of Pragmatics. London:Longman.

Mahmud, M. (2010).Politeness in Bugis: A Study in Linguistic Anthropology.Vol. 1 and 2.Makassar:Badan Penerbit UNM.

Markus, S. (2013). An Analysis of Politeness Strategies in Online Learning and Teaching.TEFLIN Journal, Vol. 24, no.1, January 2013.

Mills, S. (2003).Gender and Politeness.Cambridge:Cambridge University Press.

Ogiermann, E. (2009). On Apologizing Negative and Positive Politeness Cultures.Amsterdam: John Benjamins Publishing Company.

Parker, J. (1986).Towards an Anatomy of Impoliteness.Journal of Pragmatics 25(3), 349367.

Robinson, J. (1993). Discourse studies: An introductory textbook. Amsterdam: John Benjamins Publishing Company.

Scollon, R., and Scollon, S.W. (1995).Intercultural Communication: A Discourse Approach.Oxford: Blackwell.

Watts, Richard J. 2003. Politeness. New York: Cambridge University Press

Watts, R. J. (1992). 'Linguistic Politeness and Politic Behavior', in Watts, R., Ide, S. and Ehlich, K. (eds.) Politeness in language: Studies in its History, theory and Practice, Mouton de Gruyter, pp. 43-70.

Yule, G. (2002). The Study of Language. Cambridge: Cambridge University Press. 
Yule, G. 1996. Pragmatics. New York: Oxford University Press 